\title{
PENINGKATAN HASIL BELAJAR MATEMATIKA MELALUI MODEL PEMBELAJARAN KOOPERATIF TIPE GUIDED INQUIRY POKOK BAHASAN GARIS SINGGUNG LINGKARAN PADA SISWA MADRASAH TSANAWIYAH
}

\author{
Abdul Kholik ${ }^{1}$, Iis Holisin², Febriana Kristanti ${ }^{3}$ \\ Pendidikan Matematika \\ Fakultas Keguruan dan Ilmu Pendidikan \\ Universitas Muhammadiyah Surabaya
}

\begin{abstract}
ABSTRAK
Penelitian ini bertujuan untuk mendeskripsikan peningkatan hasil belajar matematika dan respon siswa kelas VIII MTs Syarif Hidayatullah setelah diterapkan model pembelajaran kooperatif tipe Guided Inquiry pada pokok bahasan Garis Singgung Lingkaran. Jenis penelitian ini adalah penelitian tindakan kelas dengan subjek penelitian siswa kelas VIII MTs Syarif Hidayatulloh tahun ajaran 2014/2015. Penelitian dilaksanakan dalam dua siklus tindakan. Teknik pengumpulan data menggunakan metode tes, metode observasi, dan metode angket. Hasil penelitian menunjukkan adanya peningkatan ketuntasan hasil tes evaluasi siswa sebesar $21,88 \%$. Peningkatan hasil aktivitas siswa aspek afektif yang mendapat kriteria aktif dan cukup aktif sebesar 3,12\%. Peningkatan hasil aktivitas siswa aspek psikomotor yang mendapat kriteria terampil dan cukup terampil sebesar $25 \%$. Selain itu hasil dari angket respon siswa sebesar 84,38\% siswa dikategorikan sangat setuju dan setuju terhadap model pembelajaran kooperatfif tipe Guided Inquiry.
\end{abstract}

Kata Kunci: guided inquiry, hasil belajar, kooperatif

\section{PENDAHULUAN}

Dalam pembelajaran matematika masih terdapat kendala-kendala missalnya, pada tingkat Sekolah Menengah Pertama (SMP) pembelajaran cenderung text book oriented dan masih didominasi dengan pembelajaran yang terpusat pada guru. Pembelajaran yang terpusat pada guru mengakibatkan adanya siswa-siswa yang tidak memperhatikan penjelasan guru bahkan ramai sendiri. Disamping itu juga model pembelajaran yang digunakan guru masih cenderung konvensional.

Dengan kondisi kelas yang seperti itu hasil belajar siswa tidak bisa maksimal bahkan dibawah kriteria ketuntasan minimal. Belajar matematika menggunakan metode konvensional kurang efektif, kurang efektif ini berarti pemahaman siswa itu cepat lupa akibatnya pada pertemuan-pertemuan berikutnya siswa ditanya tidak bisa menjawab. Hal tersebut juga terjadi di kelas VIII MTs Syarif Hidayatullah, dibuktikan dengan nilai hasil belajar matematika masih $56.25 \%$ tuntas dengan kriteria ketuntasan minimal. 


\section{Abdul Kholik ${ }^{1}$, Iis Holisin ${ }^{2}$, Febriana Kristanti ${ }^{3}$}

Banyak model-model pembelajaran saat ini yang tujuannya supaya peserta didik dapat memahami materi secara mandiri. Salah satu metode yang memungkinkan dapat meningkatkan pemahaman siswa dengan baik adalah model pembelajaran dengan pendekatan Inquiry. Model pembelajaran dengan pendekatan Inquiry adalah rangkaian kegiatan pembelajaran yang menekankan pada proses berpikir secara kritis dan analisis untuk mencari dan menemukan sendiri jawaban dari suatu masalah yang dipertanyakan (Sanjaya, 2011:194). Pendekatan inkuiri terbagi menjadi tiga jenis berdasarkan besarnya intervensi guru terhadap siswa atau besarnya bimbingan yang diberikan oleh guru kepada siswanya. Ketiga jenis pendekatan inkuiri tersebut adalah Inkuiri Terbimbing (Guided Inquiry Approach), Inkuiri Bebas (Free Inquiry Approach), dan Inkuiri bebas yang Dimodifikasikan (Modified Free Inquiry Approach).

Pendekatan Inkuiri Terbimbing (Guided Inquiry Approach) merupakan pendekatan inkuiri, dimana guru membimbing siswa melakukan kegiatan dengan memberi pertanyaan awal dan mengarahkan pada suatu diskusi. Guru mempunyai peran aktif dalam menentukan permasalahan dan tahap-tahap pemecahannya. Pendekatan inkuiri terbimbing ini digunakan bagi siswa yang belum berpengalaman belajar dengan pendekatan inkuiri. Di kelas VIII MTs Syarif Hidayatullah belum pernah menggunakan model pembelajaran dengan pendekatan inkuiri, sehingga pendekatan Inkuiri Terbimbing (Guided Inquiry) tepat diterapkan di kelas tersebut. Disamping itu juga pembelajaran dengan pendekatan inkuiri terbimbing ini melatih siswa untuk mencari konsep secara mandiri sehingga dengan menemukan sendiri konsepnya siswa tidak mudah lupa.

\section{METODE PENELITIAN}

Jenis penelitian yang digunakan dalam penelitian ini adalah penelitian tindakan kelas atau biasa disingkat PTK. Secara garis besar model penelitian tindakan kelas meliputi empat hal pokok yakni: (1) perencanaan, (2) pelaksanaan, (3) pengamatan, dan (4) refleksi. Penelitian ini dilakukan dengan dua siklus. Prosedur pelaksanaan pada siklus I diawali dengan perencanaan kemudian pelaksanaan tindakan, pengamatan dan refleksi. 
Pada tahap perencanaan, peneliti mengembangkan perangkat dan instrumen pembelajaran. Setelah perangkat dan instrumen pembelajaran siap, kemudian ke tahap pelaksanaan dan pengamatan, keduanya dilaksanakan secara bersama-sama. Pada tahap refleksi peneliti menganalisa atau mengolah data yang telah dikumpulkan dengan metode-metode yang telah ditentukan. Kegiatan refleksi ini dilakukan pada akhir pembelajaran untuk membahas kekurangan dan kelebihan dari kegiatan pembelajaran yang telah dilaksanakan. Kemudian peneliti bersama guru mempertimbangkan hasil tersebut sebagai dasar untuk perencanaan pada siklus berikutnya.

Penelitian ini dilaksanakan di MTs Syarif Hidayatullah. Gedung MTs Syarif Hidayatullah berlokasi di dusun Kemuning desa Menunggal kecamatan Kedamean Gresik. Subjek penelitian ini adalah siswa kelas VIII MTs Syarif Hidayatullah yang terdiri dari 32 siswa dengan komposisi perempuan 18 siswi dan laki-laki 14 siswa.

Teknik pengumpulan data pada penelitian adalah metode tes, metode observasi, dan metode angket. Analisis data penelitian ini meliputi hasil belajar siswa dan respon siswa. Analisis data dilakukan dengan mengacu pada analisis data kuantitatif menurut Arikunto (2008:236). Keberhasilan penelitian ini dilihat dari peningkatan hasil belajar siswa sebelum tindakan dan akhir tindakan yaitu pada siklus II.

\section{HASIL PENELITIAN DAN PEMBAHASAN}

\section{Hasil}

Penelitian ini dilaksanakan dengan melakukan pembelajaran dikelas VIII MTs Syarif Hidayatulloh yang terdiri dari 32 siswa pada pelajaran matematika dengan pokok bahasan Garis Singgung Lingkaran. Terlihat pada Tabel 1, Siklus I terdiri dari 2 kali pertemuan dengan masing-masing pertemuan 2 jam pelajaran, setiap 1 jam pelajaran 35 menit. Siklus II juga terdiri dari 2 kali pertemuan dengan masing-masing pertemuan 2 jam pelajaran. 
Tabel 1: Hasil Penelitian

\begin{tabular}{|c|c|c|c|c|c|c|c|c|}
\hline \multirow[b]{2}{*}{ Aspek } & \multirow[b]{2}{*}{ Kriteria } & \multicolumn{2}{|c|}{ Sebelum Tindakan } & \multicolumn{2}{|c|}{ Siklus I } & \multicolumn{2}{|c|}{ Siklus II } & \multirow[b]{2}{*}{ Peningkatan } \\
\hline & & \begin{tabular}{|c|} 
Banyak \\
Siswa
\end{tabular} & $\%$ & $\begin{array}{c}\text { Banyak } \\
\text { siswa }\end{array}$ & $\%$ & $\begin{array}{c}\text { Banyak } \\
\text { siswa }\end{array}$ & $\%$ & \\
\hline \multirow{6}{*}{ 范 } & Nilai $\geq 71$ & 18 & $56,25 \%$ & 13 & $40,63 \%$ & 25 & $78,13 \%$ & $21,88 \%$ \\
\hline & Nilai $<71$ & 14 & $43,75 \%$ & 19 & $59,38 \%$ & 7 & $21,87 \%$ & $-21.88 \%$ \\
\hline & \begin{tabular}{|l|} 
Rata-rata \\
\end{tabular} & \multicolumn{2}{|c|}{73,47} & \multicolumn{2}{|c|}{65,88} & \multicolumn{2}{|c|}{79,12} & 5,65 \\
\hline & $\begin{array}{l}\text { Standar } \\
\text { Deviasi }\end{array}$ & \multicolumn{2}{|c|}{7,32} & \multicolumn{2}{|c|}{14,79} & \multicolumn{2}{|c|}{13,59} & 6,27 \\
\hline & \begin{tabular}{|l|} 
Tertinggi \\
\end{tabular} & \multicolumn{2}{|c|}{89} & \multicolumn{2}{|c|}{100} & \multicolumn{2}{|c|}{100} & 11 \\
\hline & Terendah & \multicolumn{2}{|c|}{66} & \multicolumn{2}{|c|}{44} & \multicolumn{2}{|c|}{56,67} & $-9,33$ \\
\hline \multirow{4}{*}{ 宽 } & Aktif & & & 11 & $34,38 \%$ & 14 & $43,75 \%$ & $9,37 \%$ \\
\hline & $\begin{array}{l}\text { Cukup } \\
\text { Aktif }\end{array}$ & & & 15 & $46,88 \%$ & 13 & $40,63 \%$ & $-6,25 \%$ \\
\hline & $\begin{array}{c}\text { Kurang } \\
\text { Aktif }\end{array}$ & & & 6 & $18,75 \%$ & 5 & $15,63 \%$ & $-3,12 \%$ \\
\hline & $\begin{array}{l}\text { Tidak } \\
\text { Aktif }\end{array}$ & & & 0 & $0 \%$ & 0 & $0 \%$ & $0 \%$ \\
\hline \multirow{4}{*}{ 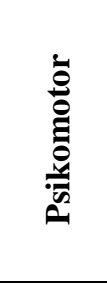 } & Terampil & & & 11 & $34,38 \%$ & 11 & $34,38 \%$ & $0 \%$ \\
\hline & \begin{tabular}{|c|} 
Cukup \\
Terampil \\
\end{tabular} & & & 10 & $31,25 \%$ & 18 & $56,25 \%$ & $25 \%$ \\
\hline & \begin{tabular}{|c|} 
Kurang \\
Terampil \\
\end{tabular} & & & 11 & $34,38 \%$ & 3 & $9,38 \%$ & $-25 \%$ \\
\hline & \begin{tabular}{|c|} 
Tidak \\
Terampil
\end{tabular} & & & 0 & $0 \%$ & 0 & $0 \%$ & $0 \%$ \\
\hline
\end{tabular}

Berdasarkan Tabel 4.10, ketuntasan hasil belajar pada aspek kognitif siklus I menurun dibanding sebelum tindakan. Rata-rata nilai tes evaluasi siklus I 65,88 dengan standar deviasi 14,79. Pada siklus II ketuntasan belajar naik menjadi 78,13\%. Rata-rata nilai tes evaluasi siklus II 79,12 dengan standar deviasi 13,59. Ketuntasan 78,13\% artinya sudah melebihi indikator keberhasilan.

Pada aspek afektif, sebelum tindakan aktivitas siswa belum tampak karena model pembelajarannya menggunakan konvensional. Pada siklus I, aktivitas siswa aspek afektif diperoleh $81,25 \%$ siswa yang memdapat kriteria aktif dan cukup aktif. Pada siklus II siswa yang mendapat kriteria aktif dan cukup aktif meningkat menjadi $84,38 \%$. Hasil aktivitas siswa aspek afektif tersebut sudah melebihi indikator keberhasilan.

Pada aspek psikomotor, sebelum tindakan aktivitas siswa belum tampak karena model pembelajarannya menggunakan konvensional. Pada siklus I, aktivitas siswa aspek psikomotor diperoleh $65,63 \%$ siswa yang memdapat kriteria terampil dan cukup terampil. Pada siklus II siswa yang mendapat kriteria terampil dan cukup 
terampil meningkat menjadi 90,63\%. Hasil aktivitas siswa aspek psikomotor tersebut sudah melebihi indikator keberhasilan.

Hasil belajar pada siklus I, aspek kognitif dan aspek psikomotor belum mencapai indikator keberhasilan sehingga penelitian dilanjutkan pada siklus II. Hasil belajar siklus II, aspek kognitif, aspek afektif, dan aspek psikomotor sudah melebihi indikator keberhasilan sehingga penelitian ini dikatakan berhasil.

\section{Pembahasan}

Peneliti mengambil data awal sebelum tindakan yaitu nilai UAS semester ganjil tahun pelajaran 2014/2015 kelas VIII MTs Syarif Hidayatulloh. Hasil UAS tersebut menunjukkan 56,25\% siswa yang tuntas dari kriteria ketuntasan minimal. Hasil tersebut menunjukkan hasil belajar siswa masih perlu ditingkatkan.

Berdasarkan hasil observasi terhadap aktivitas guru dalam mengelolah pembelajaran dan aktivitas siswa dalam mengikuti pembelajaran pada siklus I, kegiatan pembelajaran belum terlaksana secara optimal. Hal ini disebabkan metode pembelajaran yang digunakan agak sedikit berbeda dengan biasanya. Kecenderungan belajar individu mengakibatkan kurangnya komunikasi dan kerjasama dalam kelompok. Dalam pembelajaran yang telah dilaksanakan dapat dilihat bahwa siswa yang berkemampuan rendah hanya bergantung pada teman sekelompoknya yang berkemampuan lebih. Pada model kooperatif, siswa kemampuan lebih dapat membantu kemampuan di bawahnya pada saat proses interaksi dengan kelompoknya. Namun, siswa berkemampuan rendah dalam proses penyelesaian masalah tidak berkembang karena hanya bertumpu pada siswa berkemampuan lebih.

Berdasarkan hasil observasi terhadap aktivitas guru dalam mengelolah pembelajaran dan aktivitas siswa dalam mengikuti pembelajaran pada siklus II, pembelajaran berjalan lebih baik dari sebelumnya, baik dari siswa yang mengikuti pembelajaran maupun peneliti dalam menjelaskan materi dan membimbing siswa. Proses pembelajaran di kelas telah berpusat pada siswa. Walaupun masih ada siswa keliru dalam mengisi tabel kebenarannya, namun bisa teratasi dengan bimbingan dari peneliti. Peneliti memberikan bimbingan untuk mengarahkan siswa agar menemukan konsep yang dipelajarinya. Bimbingan tidak hanya diberikan kepada 


\section{Abdul Kholik ${ }^{1}$, Iis Holisin' ${ }^{2}$, Febriana Kristanti ${ }^{3}$}

individu/kelompok itu saja, tetapi seluruh siswa di kelas. Selama proses pembelajaran, kelas dibentuk menjadi beberapa kelompok diskusi untuk memudahkan membimbing siswa, selama diskusi berlangsung siswa bertanya kepada peneliti saat mengalami kesulitan. Namun, pertanyaan-pertanyaan tersebut tidak langsung dijawab oleh peneliti. Peneliti meminta siswa untuk lebih cermat mendiskusikan hal yang ditanyakan, jawaban harus ditemukan sendiri oleh siswa. Oleh karena itu, peneliti membimbing siswa dengan petunjuk tambahan untuk membantu mengarahkan menemukan jawaban pertanyaan atau konsep yang dipelajari, petunjuk tidak diberikan hanya kepada kelompok yang bertanya saja, tetapi kepada semua siswa di kelas. Hal ini dilakukan agar tidak terjadi pengulangan pertanyaan oleh siswa/kelompok lain. Dengan demikian, proses pembelajaran benar-benar terpusat pada siswa, siswa berusaha menggunakan dan mencari ide untuk menemukan suatu konsep.

Dalam proses penemuan, siswa dibantu oleh LKS yang diberikan dan bimbingan oleh peneliti. Siswa yang berada satu kelompok saling berinteraksi dalam menyelesaikan permasalahan yang terdapat pada LKS. Jika siswa belum mengerti dalam menyelesaikan masalah tersebut, siswa bisa berinteraksi dengan teman kelompoknya dan guru. Interaksi berupa sharing atau siswa yang berkemampuan lemah bertanya kepada siswa yang pandai dan siswa yang pandai menjelaskannya. Interaksi juga terjadi antara guru dengan siswa tertentu, dengan beberapa siswa atau serentak dengan seluruh siswa dalam kelas. Guru hanya mengarahkan siswa untuk menyelesaikan masalah yang diberikan dan siswa yang mengkonstruksi sendiri pengetahuannya. Siswa mendapat bantuan dari guru, bantuan yang diberikan menggunakan teknik scaffolding. Teknik scaffolding merupakan suatu teknik memberi bantuan kepada siswa yang mengalami kesulitan di atas kemampuannya dalam memecahkan masalah, antara lain berupa pengajuan pertanyaan dan pemberian petunjuk, pertanyaan yang diberikan oleh guru berbentuk pertanyaan yang lebih sederhana dan lebih mengarahkan siswa untuk dapat untuk mengonstruksi konsep. Bentuk pertanyaan tersebut merupakan lanjutan dari pertanyaan yang dituangkan dalam LKS, bantuan yang diberikan bukan untuk individu melainkan untuk kelompok yang mengalami kendala dalam melakukan proses penemuan berdasarkan langkah-langkah penemuan dalam LKS. 
Langkah-langkah penemuan yang disajikan dalam LKS yaitu merumuskan masalah, menganalisis data, menguji, dan membuat kesimpulan. Langkah-langkah yang perlu ditempuh oleh guru matematika jika ingin pelaksanaan metode penemuan terbimbing berjalan dengan efektif, adalah 1) merumuskan masalah yang akan diberikan kepada siswa dengan data secukupnya, perumusannya harus jelas, hindari pernyataan yang menimbulkan salah tafsir sehingga arah yang ditempuh siswa tidak salah. 2) Dari data yang diberikan guru, siswa menyusun, memproses, mengorganisir, dan menganalisis data tersebut. Dalam hal ini, bimbingan guru dapat diberikan sejauh yang diperlukan saja. Bimbingan ini sebaiknya mengarahkan siswa untuk melangkah ke arah yang hendak dituju, melalui pertanyaan-pertanyaan, atau LKS. 3) Siswa menyusun hipotesis dari hasil analisis yang dilakukannya. 4) Bila dipandang perlu, hippotesis yang telah dibuat siswa tersebut diatas diperiksa oleh guru. Hal ini penting dilakukan untuk meyakinkan kebenaran prakiraan siswa, sehingga akan menuju arah yang hendak dicapai. 5) Apabila telah diperoleh kepastian tentang kebenaran konjektur tersebut, maka verbalisasi konjektur sebaiknya diserahkan juga kepada siswa untuk menyusunnya. Di samping itu, perlu diingat pula bahwa induksi tidak menjamin $100 \%$ kebenaran konjektur. 6) Sesudah siswa menemukan apa yang dicari, hendaknya guru menyediakan soal latihan atau soal tambahan untuk memeriksa apakah hasil penemuan itu benar.

Hasil tes akhir tindakan siklus I, diperoleh bahwa masih banyak siswa yang belum mampu menyelesaikan soal. Hasil tes siklus I menurun dari hasil nilai sebelum tindakan yaitu nilai UAS. Akan tetapi, hasil aktivitas siswa meningkat, artinya siswa mengikuti jalannya pembelajaran dengan sesuai langkah-langkah yang ada. Hasil tes akhir siklus I ini belum mencapai kriteria keberhasilan tindakan yang telah ditetapkan. Hasil tes akhir tindakan siklus II menunjukkan bahwa terjadi peningkatan dibanding hasil tes akhir siklus I. Disamping itu juga hasil observasi aktivitas siswa juga mengalami peningkatan. Hasil tes akhir siklus II ini telah mencapai kriteria keberhasilan tindakan yang telah ditetapkan. Sehingga dapat disimpulkan hasil belajar siswa dapat meningkat dengan menerapkan pembelajaran kooperatif tipe Guided Inguiry. 


\section{Abdul Kholik' ${ }^{1}$ Iis Holisin' ${ }^{2}$, Febriana Kristanti ${ }^{3}$}

Hasil respon siswa terhadap model pembelajaran kooperatif tipe Guided Inquiry. Pengambilan data respon siswa ini dengan memberikan angket yang berisi 25 pernyataan tentang model pembelajaran kooperatif tipe Guided Inquiry. Hasil respon siswa yang dikategorikan sangat setuju terhadap model pembelajaran kooperatfif tipe Guided Inquiry sebesar 43,75\%. Sebesar 40,63\% siswa dikategorikan setuju terhadap model pembelajaran kooperatfif tipe Guided Inquiry. Sebesar 15,63\% siswa dikategorikan kurang setuju terhadap model pembelajaran kooperatfif tipe Guided Inquiry.

\section{SIMPULAN}

Berdasarkan hasil dan pembahasan di atas, penerapan model pembelajaran kooperatif tipe Guided Inquiry dapat meningkatkan hasil belajar siswa pada materi garis singgung lingkaran di kelas VIII MTs Syarif Hidayatulloh, yaitu merumuskan masalah, menyusun hipotesis, menganalisis data, menguji hipotesis , dan membuat kesimpulan. Pada tahap merumuskan masalah, siswa diminta untuk berpikir bagaimana cara menyelesaikan masalah yang diberikan. Pada tahap menyusun hipotesis, siswa diminta memikirkan jawaban sementara dari rumusan masalah. Guru memberikan penjelasan-penjelasan mengenai masalah yang ada sehingga siswa dapat memperkirakan jawaban sementara. Selanjutnya tahap menganalisis data, siswa menganalisis langkah-langkah kerja yang ada disetiap LKS yang sudah tersedia. Pada tahap ini guru membimbing siswa dalam menganalisis data sehingga siswa tidak keluar dari materi yang dipelajari. Pada tahap menguji hipotesis, siswa menjawab pertanyaan-pertanyaan yang ada di LKS. Selanjutnya siswa membuat kesimpulan dari hasil yang diperoleh. Tahap-tahap model pembelajaran kooperatif tipe Guided Inquiry ini dapat dilihat dengan bantuan LKS yang diberikan oleh peneliti. Dalam pembelajaran ini, siswa tidak lepas dari bantuan dan bimbingan dari peneliti agar lebih terarah.

\section{DAFTAR PUSTAKA}

Arikunto, dkk. 2011. Penelitian Tindakan Kelas. Jakarta: Bumi Aksara

Arikunto, Suharsimi. 2008. Dasar Dasar Evaluasi Pendidikan. Jakarta: Bumi Aksara

Dimyati \& Mudjiono. 2013. Belajar dan Pembelajaran. Jakarta: Rineka Cipta 
Hamiyah, Nur dan Jauhar, Muhammad. 2014. Strategi Belajar Mengajar Di Kelas. Jakarta: Prestasi Pustaka Jakarta

Kuhlthau, dkk . 2007. Guided Inquiry Learning in the $21^{\text {st }}$ Century. (Online). Tersedia: http://www.mediafire.com/view/?yyq1u548pp9wb73. Diakses pada tanggal 12 Januari 2015

Lie, Anita. 2010. Mempraktikkan Cooperative Learning di Ruang-Ruang Kelas. Jakarta: PT. Grasindo

Lindawati, Sri. Pembelajaran Matematika dengan Pendekatan Inkuiri Terbimbing untuk Meningkatkan Kemampuan Pemahaman dan Komunikasi Matematis Siswa Sekolah Menengah Pertama. Jurnal (Online). Tersedia: http://ejournal.unri.ac.id/index.php/JP/article/download/997/990. Diakses pada tanggal 12 Januari 2015

Nuharini, Dewi dan Wahyuni, Tri. 2008. Matematika Konsep dan Aplikasinya kelas VIII. Jakarta : Pusat perbukuan departemen pendidikan nasional Sanjaya Wina. 2006. Strategi Pembelajaran Berorientasi Standar Proses Pendidikan. Rawamangun-Jakarta: Kencana Perdana Media Group

Nurcholis. 2013. Implementasi Metode Penemuan Terbimbing untuk Meningkatkan Hasil Belajar Siswa pada Penarikan Kesimpulan Logika Matematika. Jurnal (Online). Vol. 01, No. 01. Tersedia: http://jurnal.untad.ac.id/jurnal/index.php/JEPMT/article/download/1707/ 1124. Diakses pada 12 Januari 2015

Sanjaya, Wina. 2011. Strategi Pembelajaran Berorientasi Standar Proses Pendidikan. Jakarta: Kencana Prenda Media

Sardiman. 2007. Interaksi dan Motivasi Belajar Mengajar. Jakarta: PT. Raja Grafindo Persada

Slameto. 2010. Belajar dan Faktor-Faktor yang Mempengaruhinya. Jakarta: Rineka Cipta

Sudjana, Nana. 2006. Penilaian Hasil Proses Belajar Mengajar. Bandung: PT. Remaja Rosdakarya

Sugiyono. 2011. Metode Penelitian Kualitatif Kuantitatif dan R\&D. Bandung: Alfabeta

Syah, Muhibbin. 2012. Psikologi Belajar. Jakarta: Rajawali Press

Trianto. 2011. Model-Model Pembelajaran Berorientasi Kontruktivistik. Jakarta: Prestasi Pustaka Publisher 